\title{
Quality of Life and Depressive Symptoms in the Elderly Living in Community
}

Anna Mikaelly de Sousa Tavares Assis', Maria de Lourdes Farias Pontes ${ }^{2}$, Maria do Carmo Andrade Duarte de Farias ${ }^{3}$, Edilene Araújo Monteiro ${ }^{2}$, Cleane Rosa da Silva ${ }^{1}$, Renata Rabelo Pereira ${ }^{2}$, Francisco Alírio da Silva ${ }^{3}$, Andréia Karla Anacleto de Sousa ${ }^{3}$, Jéssica Moura Cartaxo ${ }^{4}$, Ricardo Lourenço Coelho ${ }^{3}$, Cláudia Jeane Lopes Pimenta ${ }^{5}$

\section{Abstract}

Introduction: The elderly are affected by some chronic diseases that require comprehensive and continuous health care, among them depression, with disabling potential, compromising their quality of life.

Objective: Discovering the quality of life of seniors residing in community and their relationship with the symptoms of depression.

Method: A quantitative study, observational, cross-sectional, whose sample included 110 elderly with preserved cognitive conditions and who agreed to participate voluntarily. Data collection was conducted from October to December 2013. Statistical analysis was performed using the software Statiscal Package for Social Sciences (SPSS), version 20.

Results: The quality of life assessed by the WHOQOL-BREF obtained the highest score in the field of social relations (73.93) and lowest score in the environmental field (61.27). The WHOQOL-OLD showed a higher score in sensory abilities facet (76.19) and lowest score on the facet autonomy (61.47). The correlation of quality of life with depressive symptoms presented the psychological domain and facet social participation with strong and negative association.

Conclusion: The development of longitudinal studies becomes feasible for a better understanding of the phenomenon studied.
1 Student of Nursing, Federal University of Paraiba - UFPB, Brazil.

2 Health's Sciences Center, Federal University of Paraiba - UFPB, João Pessoa, Paraíba, Brazil.

3 Academic Unit of Life Sciences, Teacher's Training Center, Federal University of Campina Grande, Cajazeiras, Paraíba.

4 Bachelor of Medicine, Federal University of Campina Grande, Cajazeiras, Paraíba, Brazil.

5 Bachelor of Nursing, Federal University of Campina Grande, Cajazeiras, Paraíba, Brazil.

Contact information:

Maria do Carmo Andrade Duarte de Farias.

झ carmofarias@hotmail.com 


\section{Introduction}

Currently, aging is part of the reality of most societies, being the result of the association between the decline in fertility and mortality rates and increased life expectancy. In developing countries, such as Brazil, this reality has been going on at an accelerated rate, except there has been a reorganization in healthcare, required to meet this new demand [1].

With the extension of life, the elderly experiencing some events and losses in various aspects, such as social isolation, widowhood, death of friends and neighbors, fear of dying, difficulty in establishing new ties and the emergence or worsening of chronic diseases, which makes it vulnerable to depression. In Brazil, depression is among the most common psychiatric disorders in the elderly, with a prevalence ranging from $4.8 \%$ to $14.6 \%$ for those living in the community [2].

Depression presents as striking symptoms, depressed mood and loss of interest in part of the activities. It is considered a multifactorial disorder of affective area or mood, which triggers strong functional impact involving various aspects of biopsychosocial order [3]. In the elderly, the disorder manifests itself in different ways and can be mistaken for other diseases or as a result of aging [4].

Such manifestation causes depression is difficult to diagnose in the elderly. Faced with this problem, there is in Primary Health Care (PHC) the unpreparedness of some professionals in dealing with this disorder that cycle of life, which confirms low rates of identification and treatment of depression at this level of attention [1]. Study indicates that the PHC of services are important spaces for screening depressive symptoms by applying the short Geriatric Depression Scale (GDS) at the time of nursing consultation [5].

During life, the elderly are affected by numerous chronic diseases that require comprehensive and continuous health care, and depression is on that list as pathology potentially incapacitating, negatively affecting the quality of life $(\mathrm{QoL})$ of this age group
[6]. According to the World Health Organization, QoL corresponds to the "individual's perception of his position in life in the context of his culture and values system he lives in, and in relation to his goals, expectations, standards and concerns" [7]. It is a concept with wide significance and is related to social, environmental, economic, biological and psychic order [8].

A cross-sectional study conducted in São Paulo, to relate the domains of WHOQOL-Bref with the GDS showed that the higher the scores for depressive symptoms, the worse QoL scores of the elderly. The GDS decreased the score of the physical, psychological, environmental and general domains [9].

Quality of life in old age is of a new sensitivity in health and social order, it is considered a problem and a challenge for society [10]. Thus, given the impact that symptoms of depression generate the QoL of the elderly, it is necessary to know this event those residing in communities in order to contribute to the planning of actions and strategies in terms of PH, aimed at early detection and effective treatment, and reducing this disease effects on QoL of the elderly.

Thus, the goal was to investigate the QoL of elderly people who lived in the community, and their relationship with the symptoms of depression.

\section{Method}

It is a quantitative study, observational and crosssectional, developed in two Family Health Units (FHU) located in the city of João Pessoa - PB. A simple random sample consisted of 110 elderly men and women.

Inclusion criteria were: being 60 years old or over, living in households registered in FHUs, presenting preserved cognitive conditions. There were excluded from the study older adults with cognitive and hearing impairment.

Data collection was conducted from October to December 2013 in the seniors' homes through in- 
terviews subsidized by four instruments. Before start collecting, the visits were made in FHUs to collect the names and addresses of registered seniors, for subsequent visit in their homes.

Initially, we used a structured questionnaire to obtain the sociodemographic characteristics of the elderly, including: aspects of identification, age, gender, education, marital status, living arrangements and individual monthly income.

Then applied the WHOQOL-BREF and WHOQOLOLD to evaluate the QoL of the elderly. The WHOQOL-BREF is an instrument with satisfactory psychometric properties and use of convenience for QoL research in Brazilian elderly. It has 26 questions, two related to global QoL and general health, and 24 others are categorized into four domains (physical, psychological, social relationships and environmental). The response to each item of the questionnaire varies between 1 and 5 [10].

The WHOQOL-OLD consists of 24 items recorded in a Likert scale of five points, divided into six facets (sensory abilities, autonomy, past, present and future activities, social participation, death and dying, and intimacy). It is a specific complementary instrument that provides additional information regarding the QoL of this population. The final scores of each facet domain were calculated using a syntax, a scale ranging from 0 to 100 . The closer to 100 , the better the individual's QoL [11].

We used the short Geriatric Depression Scale (GDS-15) to trace the presence or absence of symptoms of depression. It is an instrument recommended by the Ministry of Health of Brazil, rapid assessment to detect depression in elderly patients in PHC [1]. This scale has been validated in Brazil [12] and consists of 15 questions, which includes dichotomous answers (yes or not) and a score ranging from 0 to 15 points and includes the following cut-off points: less than or equal to 5 points means individual normal or without depressive symptoms; over 5 points, with individual symptoms of depression [12].
To organize the data, the information was stored in a structured spreadsheet in Microsoft Excel 2010 for Windows, with double entry. Statistical analysis was performed using the software Statiscal Package for Social Sciences (SPSS) version 20.

The internal consistency of items in each WHOQOL-BREF domain and WHOQOL-OLD was assessed by Cronbach's coefficient, whose value varies from zero to one, and the higher the value, the greater the congruence between the items, indicating homogeneity as the same phenomenon [13].

For exploratory analysis we calculated the distribution measures (mean, median, standard deviation and absolute frequency), considering the variables of interest for the characterization of study participants. For the correlation between the variables we used the Pearson correlation test, in which we considered the following classification: weak if $r<$ 0.3 ; moderate, $0.3 \leq r<5$ and strong, $0.5 \leq r$ $<1.00$. The significance level used throughout the study was 0.05 [14].

This research is part of a research: Quality of life, functional capacity and health status of elderly patients in the service of Basic Health Care, approved by the Research Ethics Committee of the University Hospital Lauro Wanderley, with Opinion no 138.228 , $30^{\text {th }}$ October, 2012. Information about the research and after signing the Informed Consent proceeded to the interview provided.

\section{Results}

Among the 110 participants, there was a higher percentage of elderly of $60-64$ years old (25.4\%), in both sexes, and female predominance (64.5\%). Regarding education, it was found that $33.6 \%$ of them had 1-4 years of study, followed by $29.1 \%$ with 12 or more years of study; $69.1 \%$ were married; most reported a monthly income of up to 1 minimum wage (37.3\%), a family arrangement consisting of spouse and child (28.2\%). 
The measurement of QoL of the elderly, through the domains of WHOQOL-BREF and facets of WHOQOL-OLD, are in Table 1. Through the WHOQOLBREF was obtained higher scores in social relationships domain (73.93) and lowest score in the environmental field (61.27). While in the WHOQOLOLD showed a higher score in sensory abilities facet (76.19) and lowest score on the facet autonomy (61.47).

Table 1. Distribution of the domains and facets of QoL. João Pessoa, PB, 2015.

\begin{tabular}{|l|c|c|c|c|}
\hline $\begin{array}{l}\text { Domains/Facets } \\
\text { WHOQOL-BREF }\end{array}$ & Average & Median & SD & a Cronbach \\
\hline $\begin{array}{l}\text { Physical } \\
\text { Psychological }\end{array}$ & 67.95 & 71.42 & 14.62 & 0.70 \\
\hline $\begin{array}{l}\text { Social } \\
\text { Relationships }\end{array}$ & 73.93 & 75.00 & 12.11 & 0.55 \\
\hline $\begin{array}{l}\text { Environmental } \\
\text { WHOQOL-BREF }\end{array}$ & 61.27 & 62.50 & 11.47 & 0.60 \\
\hline $\begin{array}{l}\text { Sensory Skills } \\
\text { Autonomy }\end{array}$ & 76.19 & 87.50 & 23.92 & 0.83 \\
\hline $\begin{array}{l}\text { Past-Present- } \\
\text { Future Activities }\end{array}$ & 66.47 & 62.50 & 17.17 & 0.68 \\
\hline $\begin{array}{l}\text { Social } \\
\text { Participation }\end{array}$ & 64.26 & 62.50 & 15.51 & 0.64 \\
\hline $\begin{array}{l}\text { Death and } \\
\text { Dyeing }\end{array}$ & 70.05 & 81.25 & 25.70 & 0.75 \\
\hline \begin{tabular}{l} 
Intimacy \\
\hline
\end{tabular} & 68.46 & 71.87 & 16.11 & 0.75 \\
\hline
\end{tabular}

The internal consistency of the domains of WHOQOL-BREF and facets of WHOQOL-OLD was assessed by Cronbach's reliability coefficient. The amounts recorded in Table 1 attest to a satisfactory internal consistency for the domains and facets. It is observed that the psychological, social relations and social participation facet have the lowest values of Cronbach's coefficient.

Table 2 shows the characterization of the elderly investigated regarding the symptoms of depression. Through analysis of GDS-15, it was found that 73 elderly subjects (66.4\%) had lower scores than 5, featuring no manifestation of depressive symptoms. $37(36.6 \%)$ remaining hit score higher than 5, indicating the presence of depressive symptoms.

Identifying the symptoms of depression among the elderly under study it was interfered with by some items of GDS-15 that were more frequent, such as "left many of his interests and activities" (item 2) answered by $62.7 \%$ and "prefer to stay at home to go out and do new things" (item 9) affirmed by $58.2 \%$ of the sample (data not shown in table).

Table 2. Characterization of the elderly $(n=110)$ regarding the symtoms of depression. João Pessoa, PB, 2015.

\begin{tabular}{|l|c|c|}
\hline GDS-15 (symptoms of depression) & $\mathbf{n}$ & $\%$ \\
\hline Present & 37 & 36.6 \\
\hline Absent & 73 & 66.4 \\
\hline & Source: Research data \\
\hline
\end{tabular}

Table 3. Pearson correlation coefficient between the domains of the WHOQOL-BREF and facets of WHOQOL-OLD with symptoms of depression. João Pessoa, PB, 2015.

\begin{tabular}{|c|c|c|}
\hline \multirow{2}{*}{ Domains/Facets } & \multicolumn{2}{|c|}{ Symptoms of Depression } \\
\hline & $r$ & $p^{*}$ \\
\hline \multicolumn{3}{|l|}{ WHOQOL-BREF } \\
\hline Physical & $-0.397 *$ & $<0.001$ \\
\hline Psychological & $-0.557^{*}$ & $<0.001$ \\
\hline Social Relationships & $-0.237^{*}$ & 0.013 \\
\hline Environmental & $-0.479 *$ & $<0.001$ \\
\hline \multicolumn{3}{|l|}{ WHOQOL-BREF } \\
\hline Sensory Skills & $-0.281^{*}$ & 0.003 \\
\hline Autonomy & $-0.278^{*}$ & 0.003 \\
\hline Past-Present-Future Activities & $-0.339 *$ & $<0.001$ \\
\hline Social Participation & $-0.521^{*}$ & $<0.001$ \\
\hline Death and Dyeing & $\neg-0.140$ * & 0.145 \\
\hline Intimacy & $-0.369 *$ & $<0.001$ \\
\hline
\end{tabular}


By linking the fields and facets of QoL of the elderly with symptoms of depression it was observed that the psychological domain had negative correlation and strong magnitude; physical and environmental field negative and moderate. Regarding facets, social participation showed a negative correlation of strong magnitude, participation pastpresent-future and intimacy, the correlation was negative and moderate. The sensory abilities facets and autonomy also had a negative correlation, but low magnitude, Table 3.

\section{Discussion}

Increased longevity gives public managers, researchers and health professionals the task of identifying factors that are related to increased life expectancy and how they contribute to the quality of life among older.

The results of this study show a higher proportion of young elderly, corroborating data from the latest census conducted in Brazil, [15] showed in their results a predominance of older people in the age group 60-79 years old, that is, young elderly. This fact can be explained by rapid population aging has happened in developing countries, such as Brazil, which started in the 60s of the twentieth century, the decline in the fertility rate, with an average of 6.3 children per woman in 1960 to 1.8 child in 2012 [16-17]

Regarding gender, there was a predominance of women in relation to men, a fact described in national $[2,18]$ and international [19-20] surveys. The longevity of women features the feminization process in old age, justified by some hypotheses: high male mortality rates related to violence, traffic accidents and chronic diseases; the highest rates of morbidity female, non-fatal in most chronic diseases; attention from women about the signs and symptoms of diseases and frequent demand for health care, compared to men [21].

The low education evidenced among the studied elderly may reflect the process of educational exclu- sion, which affected the Brazilian elderly, during the twentieth century, which experienced an educational model is not accessible to women and the poor [22]. This fact may interfere with the well-being of the elderly, since more education provides the best QoL; it favors better access to health care, activity aimed at cognitive and mental stimulation, and greater social inclusion [23].

Regarding marital status, the highest number of married to the detriment of widows corroborates findings from studies conducted with elderly enrolled in the Family Health Strategy (FHS) in Foz do Iguaçu-PR, Brazil [8] and in Porto Alegre-RS, Brazil [24].

Concerning the individual monthly income, it is clear that the elderly had a low income, confirming the result of a study conducted in the city of Cuiaba-MT [16].

Regarding the family arrangement, there was a greater quantity of elderly living with children and spouse. This co-residence appears to be related to good living conditions for both. However, there is evidence that young people are more favored in this type of arrangement, with regard to social exchanges and received and provided aid [25].

Regarding the QoL assessed by the WHOQOLBREF, the social relationships domain had a higher average score across all domains. This domain are personal relationships, support/social support and sexual activity [10].

The environmental domain assesses the environmental conditions experienced by the elderly, covering physical security and protection, home environment, financial resources, availability and quality of health and social care, opportunities to acquire new information and skills, participation and recreation opportunities and leisure, physical environment and transport [10]. The lower scores seen in this area may be related to the few opportunities that the elderly have to participate in recreation and leisure activities in the community; as well as the impossibility of seeking such opportunities in other areas of the city, due to low purchasing power and limited 
autonomy, due to excessive care (overprotection) of the family [19].

With regard to the areas social and environmental relationships, results similar to the findings of this present study were found in research conducted with secondary data, whose objective was to compare the perception of QoL and to identify factors associated with QoL among elderly community of Porto Alegre-RS and institutionalized elderly in Minas Gerais [26].

In WHOQOOL-OLD, the facet sensory abilities refers to the functioning of sensory loss and the loss of sensory abilities in the daily life of the elderly in relation to their ability to participate in activities and interact with people [11]. This facet achieved good average scores, with this result in line with the age rating, marked predominantly by young seniors.

The facet autonomy investigates independence, freedom or the ability of the elderly to live independently and make their own decisions [11]. The low score recorded in this study expressed that the study population has preserved its autonomy and no freedom to make decisions they would like to do in their life, when necessary, or control of their future.

About the analysis of the GDS-15, there was a prevalence of elderly who did not have symptoms of depression. However, a significant portion showed such symptoms and called the attention in this study due to the sample live in households in the community, maintaining a family relationship.

Similar results were found in research with elderly assisted in Dourados-MG FHS (34.4\%) and served by the Family Health teams from the East Sanitary District of Goiania-GO (35.1\%) [(26-27]. However, differed from study of elderly residents in the coverage area of a Family Health Unit in the city of Jequie-BA, which received $88.8 \%$ with depressive symptoms [2].

Depression when it is not identified and treated, can lead to elder to present physical, social and functional impairment, with consequent impairment of their QoL. In this sense, it is the professio- nal FHS, especially nurses, implement rapid multidimensional assessment of the elderly as a means to assess the mood and in the case of suspicion of depression, should be employed to GDS for confirmation. In addition, it is essential to distinguish symptoms of sadness with depression, being aware of the complaints by the elderly, since early detection of depressive symptoms, making the diagnosis and treatment is needed to reduce the injury risk of this disorder [1].

Regarding the correlation between the total score of GDS and QoL, it was found that there is a relationship of symptoms of depression in most domains of the WHOQOL-BREF and facets of WHOQOOL-OLD. The negative correlations found between depressive symptoms and domains/facets indicate that there is an inverse correlation where the higher the score the worse the GDS and QoL investigated.

The psychological domain of the WHOQOL-BREF investigating aspects related to positive feelings: thinking, learning, memory, concentration, self esteem, body image and appearance, negative feelings, spirituality, religion and personal beliefs of the elderly, correlated strongly with the symptoms of depression, showing that the QoL area most compromised among respondents and indicating that there is indeed a negative impact of these symptoms on QoL, with regard to the psychological size [10].

Other domains of QoL, adversely affected by depressive symptoms were physical and environmental. A survey conducted in Spain, whose objective was to study the psychometric properties of the WHOQOL-BREF and WHOQOL-OLD in a sample of 286 elderly by applying Pearson's correlation between the domains of WHOQOL-BREF with the GDS30 , showed results that corroborate this study, with regard to physical, psychological and environmental domains, while the social relationships domain had divergent results [19].

Concerning WHOQOOL-OLD facet related to social participation, strong and negative correlation reflects that depressive symptoms undertake unsa- 
tisfactorily the perception of the elderly about the way you use your time, level of activity and participation in community activities. Participation in social activities is seen as a differential element in the perspective of life of individuals, that by developing a sense of usefulness and identify anxieties, favors the condition of fullness and well-being, reinforcing the existential condition of the elderly [25]. Therefore, it is important that the implementation of public policies for social inclusion of the elderly in order to mitigate possible impacts of isolation on their mental health.

The past-present-future facet of QoL, which investigates the satisfaction of the elderly on the achievements in life, plans and aspirations for the future, also proved to be moderately impaired by depressive symptoms, as well as facet intimacy, which evaluates the ability of seniors to maintain personal and intimate relationships [11]. In this study, although the sensory abilities facets and autonomy presented a weak correlation, it is suggested that the symptoms of depression are causing negative impact on the way that older people value their senses and their ability to continue to maintain an autonomous and independent life.

\section{Conclusion}

The results of this study reinforce the importance of social support and good runs of sense in the lives of seniors. The list of domains and facets of QoL with the symptoms of depression suggests that the psychological domain and facet social participation are the dimensions of QoL more affected negatively by the depressive symptoms.

Therefore, it is essential that the PHC nurse be prepared to implement a comprehensive care to the elderly, to promote healthy aging, as recommended by the National Health Policy for Elderly People. Conducting training with this group of professionals becomes viable, so that they know how to deal with the psychological aspects in old age, provide the host, early detection of symptoms of depression, adopt prevention strategies, refer cases detected for more specific assessment and rehabilitate affected as a way to promote better QoL of elderly assisted.

As this is a cross-sectional study it could not establish a relation of cause and effect. Thus, taking into account the significant influence of depressive symptoms on QoL of the older investigated, suggest the development of longitudinal studies to better understand this phenomenon.

\section{References}

1. Ministério da Saúde. Envelhecimento e saúde da pessoa idosa. Brasília (Brasil): Ministério da Saúde, 2007.

2. Souza AS, Sena ELS, Meira EC, Silva DM, Alves MR, Pereira LC. Perfil sociodemográfico e de saúde de idosos com sintomas depressivos. Rev. enferm. UERJ. [Internet]. 2013; 21(3): 355-60. Available from: http://www.facenf.uerj.br/v21n3/v21n3a13.pdf.

3. Carreira L, Botelho MR, Matos PCB, Torres MM, Salci MA. Prevalência de depressão em idosos institucionalizados. Rev. enferm. UERJ. [Internet]. 2011;19(2): 268-73. Available from: http://www.facenf.uerj.br/v19n2/v19n2a16.pdf.

4. Chaimowicz F, Barcelos EM, Madureira MDS, Ribeiro MTF. Depressão, insônia, demências e confusão mental. In: Saúde do Idoso. $2^{\text {a }}$ ed. Belo Horizonte: Nescon/UFMG; 2013. p. 104-125.

5. Ferreira PCS, Tavares DMS, Martins NPF, Rodrigues LR, Ferreira LA. Características sociodemográficas e hábitos de vida de idosos com e sem indicativo de depressão. Rev. Eletr. Enf. [Internet]. 2013; 15(1): 197-204. Available from: http://www.fen. ufg.br/fen revista/v15/n1/pdf/v15n1a23.pdf

6. Horta ALM, Ferreira DCO, Zhao LM. Envelhecimento, estratégias de enfrentamento do idoso e repercussões na família. Rev. bras. enferm. [Internet]. 2010; 63(4): 523-8. Available from: http://dx.doi.org/10.1590/S0034-71672010000400004

7. The World Health Organization. Quality of Life assessment (WHOQOL): position paper from the World Health Organization. Soc Sci Med. 1995; 41(10): 1403-9.

8. Faller JW, Melo WA, Versa GLGS, Marcon SS. Qualidade de vida de idosos cadastrados na estratégia saúde da família de Foz do Iguaçu-PR. Esc. Anna Nery. [Internet]. 2010; 14(4): 803-10. Available from: http://dx.doi.org/10.1590/S141481452010000400021.

9. Lacerda SM, Gazzola JM, Lopes AB, Lemos NFD, Cordeiro RC. Qualidade de vida de idosos atendidos em Programa de Assistência Domiciliária. Rev. bras. geriatr. gerontol. [Internet]. 2011; 14(2): 329-42. Available from: http://revista.unati.uerj.br/ pdf/rbgg/v14n2/v14n2a13.pdf.

10. Fleck MPA, Louzada S, Xavier M, Chachamovich E, Vieira G, Santos $L$, et al. Aplicação da versão em português do instrumento abreviado de avaliação da qualidade de vida WHOQOL-bref. Rev. Saúde Pública. [Internet]. 2000; 34(2): 178-83. Available from: http://dx.doi.org/10.1590/S0034-89102000000200012. 
11. Fleck MP, ChachamovichE, TrentiniC. Developmentand validation of the Portuguese version of the WHOQOL-OLD module. Rev. Saúde Pública. [Internet]. 2006; 40(5): 785-91. Available from: http://dx.doi.org/10.1590/S0034-89102006000600007.

12. Almeida OP, Almeida SA. Confiabilidade da versão brasileira da Escala de Depressão Geriátrica (GDS) versão reduzida. Arq. Neuro-Psiquiatr. [Internet]. 1999; 57(2B): 421-6. Available from: http://dx.doi.org/10.1590/S0004-282X1999000300013

13. Fayers PM, Machin D. Quality of life. Assessment, analysis, and interpretation. Chichester: John Wiley; 2007.

14. Cohen J. Statistical power analysis for the behavioral sciences. Hillsdale: Lawrence Erlbaum; 1988.

15. Instituto Brasileiro de Geografia e Estatística (IBGE). Censo Demográfico 2010. Números Gerais do Censo. 2010. Disponível em: <http://www.censo2010.ibge.gov.br/primeiros dados divulgados/index.php?uf=25>. Acesso em: 14 fev. 2012.

16. Sudré MRS, Reiners AAO, Azevedo RCS, Floriano LA. Características socioeconômicas e de saúde de idosos assistidos pelas equipes de saúde da família. Cienc Cuid Saude. [Internet]. 2014; 14(1): 933-40. Available from: http://dx.doi.org/10.4025/ cienccuidsaude.v14i1.19794

17. Instituto Brasileiro de Geografia e Estatística (IBGE). Síntese de indicadores sociais: Uma análise das condições de vida da população brasileira - 2013. Rio de Janeiro, 2013.

18. Braga MCP, Casella MA, Campos MLN, Paiva SP. Qualidade de vida medida pelo WHOQOL-BREF: estudo com idosos residentes em Juiz de Fora/MG. Rev. APS. [Internet]. 2011; 14(1): 93-100. Available from: http://aps.ufjf.emnuvens.com.br/aps/ article/view/965/450

19. Lucas-Carrasco R, Laidlaw K, Power MJ. Suitability of the WHOQOL-BREF and WHOQOL-OLD for Spanish older adults. Aging Ment Health. 2011;15(5):595-604.

20. Chachamovich E, Fleck M, Laidlaw K, Power M. Impact of Major Depression and Subsyndromal Symptoms on Quality of Life and Attitudes Toward Aging in an International Sample of Older Adults. Gerontologist. 2008; 48(5): 593-602.

21. Marin MJS, Bazaglia FC, Massarico AR, Silva CBA, Campos RT, Santos SC. Características sócio-demográficas do atendimento ao idoso após alta hospitalar na Estratégia da Saúde de Família. Rev. esc. enferm. USP. [Internet]. 2010; 44(4): 962-8. Disponível em: http://dx.doi.org/10.1590/S0080-62342010000400015.

22. Peres MAC. Velhice e analfabetismo, uma relação paradoxal: a exclusão educacional em contextos rurais da região Nordeste. Soc. e estado. [Internet]. 2011; 26(3): 631-61. Disponível em: http://dx.doi.org/10.1590/S0102-69922011000300011.

23. Fernandes MGM, Nascimento NFS, Costa KNFM. Prevalência e determinantes de sintomas depressivos em idosos atendidos na atenção primária de saúde. Rev. Rene. [Internet]. 2010; 11(1): 1927. Available from: http://www.revistarene.ufc.br/vol11n1_pdf/ a02v11n1.pdf.

24. Nogueira EL, Rubin LL, Giacobbo SS, Gomes I, Neto AC. Rastreamento de sintomas depressivos em idosos na Estratégia Saúde da Família, Porto Alegre. Rev. Saúde Pública. [Internet]. 2014; 48(3): 368-77. Available from: http://dx.doi.org/10.1590/ S0034-8910.2014048004660.
25. Vitorino LM, Paskulin LMG, Vianna LAC. Qualidade de vida de idosos da comunidade e de instituições de longa permanência: estudo comparativo. Rev. Latino-Am. Enfermagem. [Internet]. 2013; 21(Spec): [09 telas]. Available from: http://dx.doi. org/10.1590/S0104-11692013000700002.

26. Alvarenga MRM, Oliveira MAC, Faccenda O. Sintomas depressivos em idosos: análise dos itens da Escala de Depressão Geriátrica. Acta paul. enferm. [Internet]. 2012; 25(4): 497-503. Available from: http://dx.doi.org/10.1590/S0103-21002012000400003.

27. Nunes DP, Nakatani AYK, Silveira EA, Bachion MM, Souza MR. Capacidade funcional, condições socioeconômicas e de saúde de idosos atendidos por equipes de Saúde da Família de Goiânia (GO, Brasil). Ciênc. saúde coletiva. [Internet]. 2010; 15(6): 2887-98. Available from: http://dx.doi.org/10.1590/S14138123201000060002

\section{Comment on this article:}

\section{$4 \mathbb{Q}$ in $8+\mathbf{S} P$}

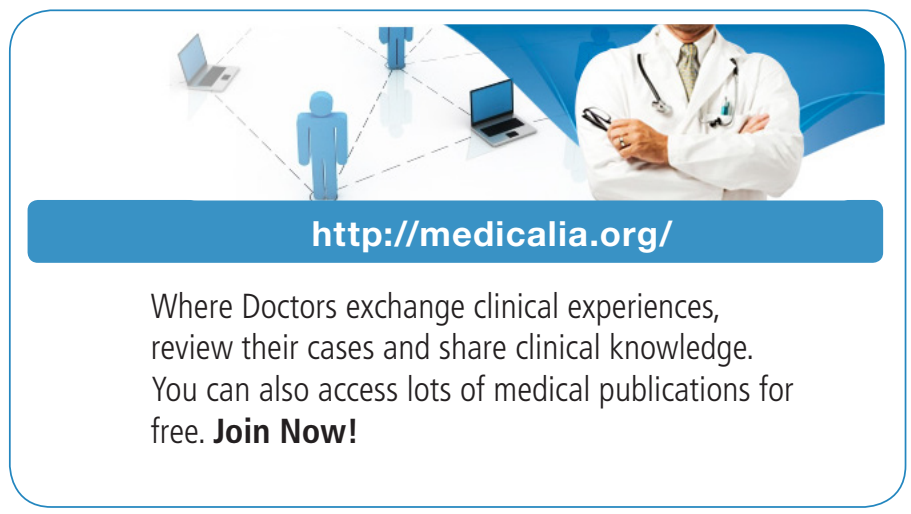

Publish with iMedPub

http://www.imed.pub

International Archives of Medicine is an open access journal publishing articles encompassing all aspects of medical science and clinical practice. IAM is considered a megajournal with independent sections on all areas of medicine. IAM is a really international journal with authors and board members from all around the world. The journal is widely indexed and classified Q1 in category Medicine. 